\title{
Ethanolic Extracts of Copaifera Multijuga Inhibits the Subcutaneous Growth of Ehrlich Carcionoma in Swiss Mice
}

\author{
Lucinéia Reuse Albiero ${ }^{1}$, Eduardo Figueiredo Nery ${ }^{1}$, Jeniffer Charlene \\ Dalazen ${ }^{1}$, Taiany Oliveira Kelly ${ }^{1}$, Débora Linsbinski Pereira ${ }^{1}$, \\ Valéria Dornelles Gindri Sinhorin ${ }^{2}$, Ramon Kaneno ${ }^{3}$, Lindsey Castoldi ${ }^{1}$ \\ ${ }^{1}$ Health Sciences Institute, Federal University of Mato Grosso - UFMT, Alexandre Ferronato Avenue n.1200, \\ Sinop, Mato Grosso, Brazil \\ ${ }^{2}$ Laboratórios Integrados de Pesquisa em Ciências Químicas (LIPEQ), Federal University of Mato Grosso - \\ UFMT, Alexandre Ferronato Avenue n.1200, Sinop, Mato Grosso, Brazil \\ ${ }^{3}$ Department of Microbiology and Immunology, Botucatu Bioscience Institute, São Paulo State University - \\ UNESP, Prof. Dr. Antônio Celso Wagner Zanin Street, Rubião Junior, Botucatu, São Paulo, Brazil
}

\begin{abstract}
Oil-resin of Copaifera multijuga Hayne is popularly used due to its anti-inflammatory properties. In this study, we evaluate the effects of the bark ethanolic extract on Ehrlich tumor cells. For extract preparation, bark was removed from stem and chopped into smaller pieces. Most were dried and grounded. The first extract was made with hexane, followed by ethyl acetate. Absolute ethanol was added to the residue and extract was filtered and concentrated (EtOH). In vitro cytotoxic activity of the EtOH was analyzed on both spleen and tumor cells. For evaluation of in vivo activity, Ehrlich carcinoma bearing Swiss mice were daily treated with different concentration of EtOH during 30 days. Evaluation of in vitro cell viability showed that $1 \mathrm{mg} / \mathrm{ml}$ extract is cytotoxic to spleen and tumor cells. Evaluation of in vivo tumor development showed that treatment with $200 \mathrm{mg} / \mathrm{kg}$ of EtOH was able to reduce in $45.28 \%$ the tumor growth. Treatment for 7 days increased IL-12p70, IFN- $\gamma$ and TNF- $\alpha$ production and for 14 days reduced the lymphoproliferative activity in both tumor bearing and mice healthy. Our results show that the ethanolic extract of copaiba bark affect Ehrlich tumor cells, reducing their cell viability in vitro as well as their development in vivo.
\end{abstract}

Keywords: Antitumor, Copaiba, Copaifera multijuga, Ehrlich tumor, Immunomodulation.

\section{Introdution}

The Amazon region is the large reserve of herbal products with medicinal effects over the planet, empirically used by local population [1]. Among these herbal products, Copaiba is popularly used for antiinflammatory, healing, antiseptic, antitumor, antibacterial, expectorant, diuretic, and analgesic purposes [2].

Copaiba (Copaifera multijuga Hayne species) trees are common in Latin America, being found in the Southeast, Midwest, and Amazon regions of Brazil [2]. The oil-resin may be extracted from the tree, which has been widely used as one of the leading marketed Amazonian natural products exported for several countries [2]. Copaiba belongs to the Leguminosae family, Caesalpinoideae subfamily, Copaifera genus, with 72 described species, 16 of them are found exclusively in Brazil [2].

Previous reports have described that Copaiba oil-resin is composed mainly of sesquiterpenes and diterpenes acids, which are assigned their anti-inflammatory and anti-tumor properties [3]. This antiinflammatory effect has been widely described and appears to be the result of high concentration of $\square$ caryophyllene $[3,4,5]$. Extracts obtained from the plant oil-resin reduced the paw oedema induced by carrageenan [4] and in zymosan-induced pleurisy model, the treatment reduced at $45 \%$ the total leukocytes infiltration and nitric oxide production by peritoneal macrophages [5].

The plant antitumor effect has also been assessed. In a study performed by Lima et al [6], animal treatment with $C$. multijuga Hayne oil-resin reduced the B16F10 melanoma growth at 58\% and the tumor weight at $76 \%$. In this study, formation of metastatic pulmonary nodules was also assessed with $47.1 \%$ reduction [6]. The copaiba antineoplastic activity was also assessed in ascitic and solid Ehrlich tumor model and authors observed that animals treated with oil-resin or fractions showed reduced tumor growth, decreasing the ascites and edema volume in the solid tumor area [7].

Activity of different extracts of copaiba on the immune system is poorly defined in the literature. Brito et al [8] suggests that the plant oil-resin may operate with an immune response modulator by stimulating or inhibiting their functions according to its compounds concentration. In fact, the authors demonstrated that in vaginal Walker tumor model and the uterine cervix, the oil-resin treatment did not reduced the tumor growth and had non-effect on infiltrating immune cells (T lymphocytes and NK cells) [8,9]. In the present study, we 
evaluated the antitumor and immunomodulatory effect of ethanolic extracts obtained from copaiba bark using the model of subcutaneous growth of Ehrlich carcinoma.

\subsection{Plant material}

\section{Materials and Methods}

The plant material was collected in particular property of Guarantã do Norte - MT (S 9'48'31.0' ' W $\left.54^{\circ} 53^{\prime} 18.0^{\prime \prime}\right)$, and it was authorized by owner and by appropriate agent of the Brazil. The specimens were identified by Professor Ivani Kuntz Gonçalves and the samples are deposited at Herbarium of Federal University of Mato Grosso - UFMT (Acervo Biológico da Amazônia Meridional - ABAM, Sinop-MT, N.4801, Prof. Dr. Domingos de Jesus Rodrigues, IBAMA, SISBIO: Número 30034-1).

\subsection{Preparation of Copaifera multijuga Hayne extracts}

Copaiba bark was removed at $5 \mathrm{~cm}$ of stem depth, cleaned, cut in small pieces and air-dried at $40^{\circ} \mathrm{C}$ during seven days. Dried material was processed in a crusher $(1.0 \mathrm{~mm})$ and macerated with different solvent for each extraction phase (2 liters/1,257 kg sample). First of all, hexane $\left(\mathrm{C}_{6} \mathrm{H}_{14} ; \mathrm{P} . \mathrm{M}:\right.$ 86.18) was added and kept for 7 days. Extract was reserved followed acetate $\left(\mathrm{CH}_{3} \mathrm{COOCH}_{2} \mathrm{CH}_{3} ; \mathrm{PM}:\right.$ 88.11) for additional seven days. Thereafter, ethanol $\left(\mathrm{C}_{2} \mathrm{H}_{5} \mathrm{OH}\right.$; PM: 46.07) was added for exhaustive maceration during nine periods of seven days. At each phase, the solvent was replaced and extract was protected of sunlight exposition. The extracts were pooled and filtered through filter paper under negative pressure, resulting in hexane raw extract, ethyl acetate and ethanolic.

A rotary vacuum evaporator $\left(\mathrm{IKA}^{\circledR} \mathrm{RV} 05\right.$ basic) at $40^{\circ} \mathrm{C}$ and vacuum desiccator was used to concentrate and remove solvents. The yields obtained were 1.652 grams for hexane extract, 5.152 grams for ethyl acetate extract and 220.463 grams for ethanol extract. All three extracts obtained were used to evaluate the toxic effect in vitro, while ethanolic extract was used for tumor and immune modulator effect in vivo.

\subsection{Experimental Design}

In vivo protocol was performed in two stages. In the first phase, the Swiss mice $(\mathrm{n}=10 ; 45 \mathrm{~g} ; 90$ days) were inoculated subcutaneously with $1 \times 10^{6}$ tumor cells followed by intragastric administration (by gavage) of $100 \mathrm{mg} / \mathrm{Kg}, 150 \mathrm{mg} / \mathrm{Kg}$ or $200 \mathrm{mg} / \mathrm{Kg}(100 \mu \mathrm{L} / \mathrm{animal})$ of ethanolic extracts or buffered saline solution (PBS) (control group) for 30 days. For calculated the percentage of growth inhibition of solid tumor we used the formula: $[\%$ inhibition $=100 \times\{($ tumor weigh control mean - tumor weigh treatment mean $) /$ tumor weigh control mean\}].

After the treatment period, the animals were euthanized and the tumor masses were excised and weigh to evaluate the effect of treatments on the tumor growth. According to the results in the $1^{\text {st }}$ phase, the best study dose was selected for immune modulator effects evaluation in the subsequent phase.

In the $2^{\text {nd }}$ phase protocol, Ehrlich bearing-mice $(\mathrm{n}=8 ; 45 \mathrm{~g} ; 90$ days) were treated daily by gavage with ethanolic extract or diluent vehicle (PBS) for 7 and 14 days. After this period, animals were euthanized for the ex vivo evaluation of lymphoproliferative activity and cytokine production by total spleen cells.

\subsection{Animals and Ethical Aspects}

Male Swiss mice, aged 40 to 50 days were obtained from the Central Animal Facility of Federal University of Mato Grosso - UFMT, Cuiabá (Brazil). Animals were kept in polypropylene boxes at $22^{\circ} \mathrm{C}$, and a $12 / 12 \mathrm{~h}$ light/dark cycles, receiving filtered water and pelleted feed (Purina, Brazil) ad libitum. All procedures were conducted in accordance to the recommendations of the Brazilian College of Animal Experimentation and were approved by the Ethics Committee on Animal Use (Comitê de Ética no Uso de Animais - CEUA) of Federal University of Mato Grosso - UFMT (CEUA Protocol nº 23108.700603/14-3).

\subsection{Total Spleen Cells Suspensions}

Spleen cell suspensions were obtained by teasing the spleens on a sterile fine nylon screen in RPMI 1640 medium (Cultilab, Campinas - SP, Brazil). The cell suspensions were centrifuged at 1,500 rpm for $10 \mathrm{~min}$ and suspended in $1 \mathrm{ml}$ of complete medium (RPMI 1640 suplemented with $20 \%$ of heat-inactivated fetal bovine serum - Cultilab, Campinas, SP, Brazil).

\subsection{Ehrlich Tumor}

Ehrlich tumor was kindly provided by Rondon Tosta Ramalho, Ph.D., from Federal University of Mato Grosso do Sul, Campo Grande, Brazil and was maintained through intraperitoneal inoculation (ascitic form) in Swiss mice, every 7 days. Tumor cells suspensions were prepared in sterile PBS, to final concentration of $1 \times 10^{7}$ viable cells $/ \mathrm{ml}$. Mice were inoculated subcutaneously in the right flank region $(0.1 \mathrm{~mL} / \mathrm{animal})$. Viability, assessed by Trypan Blue dye exclusion method, was always found to be at least $70 \%$. 


\subsection{Cytotoxicity assay by Trypan Blue exclusion method}

The toxic effect of copaiba extracts was performed by measuring the viability of both spleen cells and Ehrlich tumor cells. Two animals were used (male Swiss mice) to prepare the spleen cells suspension, following the protocol described in the section 2.5. One animal bearing ascitic form of Ehrlich tumor was the source of tumor cells. At $4 \times 10^{6} \mathrm{cel} / \mathrm{ml}$ were distributed in triplicate $(50 \mu \mathrm{L} /$ well) on 96 - flat bottowed wells microculture plate and the effect of hexane, ethyl acetate and ethanolic extract were tested in concentrations ranging from $0,25 \mathrm{mg} / \mathrm{ml}$ to $1 \mathrm{mg} / \mathrm{ml}$. Serial dilution was performed to $0.5 \mathrm{mg} / \mathrm{ml}$ and $0.25 \mathrm{mg} / \mathrm{ml}$ for each extracts preparation. Basal control group was received $50 \mu \mathrm{l} /$ wells of complete medium. The plates were cultured for $24 \mathrm{~h}$ at $37^{\circ} \mathrm{C}$ under $5 \% \mathrm{CO}_{2}$. After this period, the cell viability was assessed by Trypan blue exclusion method in a Neubauer chamber.

\subsection{Lymphocyte proliferation assay}

Cell suspensions (as described in section 2.5) containing $4 \times 10^{6}$ cells $/ \mathrm{ml}$ were distributed on 96-well microculture plates $(50 \mu \mathrm{l} /$ well) and concanavalin A (ConA, Sigma Aldrich, St. Louis - MO) at 3.5 $\mu \mathrm{g} / \mathrm{ml} \mathrm{was}$ added to each well. The plates were cultured for $72 \mathrm{~h}$ at $37^{\circ} \mathrm{C}$ under $5 \% \mathrm{CO}_{2}$ tension. The colorimetric assay (MTT based) for the non-radioactive quantification of cell proliferation was used to evaluate spleen cell response to mitogen (Cell proliferation Kit I, Roche Applied Science, Germany). Optical density was read at $630 \mathrm{~nm}$ in a Thermo plate TP-reader. The lymphoproliferative activity of spleen cells of mice treated with EtOH extracts was calculated according to the following formula: \% lymphoproliferation $=[(\mathrm{DO}$ Con $\mathrm{A}-\mathrm{DO}$ basal $) /$ (DO basal))] x 100 .

\subsection{Cytokines determination in the culture supernatant}

Quantification of cytokines in culture supernatants was done by enzyme-linked immunosorbent assay (ELISA) using the reagents from eBioscience (San Diego, CA, USA) following the indications of manufacturer. Cell culture supernatant stimulated in vitro with Con A $(3.5 \mu \mathrm{g} / \mathrm{ml})$ for $24 \mathrm{~h}$ to IL-4, IL-10 and IFN- $\square$ analysis or Staphylococos aureus formalized cells (SAC 1:5,000) for 48 h to generate TNF- $\alpha$ and IL-12.

\subsection{Statistical Analysis}

Statistical analysis was performed utilizing the Graphpad Instat software, San Diego, California - USA. Analysis of variance (ANOVA) and Tukey-Kramer tests were employed. Differences were considered significant when the probability of error was lower then $5 \%(\mathrm{p} \leq 0.05)$.

\subsection{In Vitro Cytotoxicity of Copaiba Extracts}

\section{Results}

Effect of different copaiba extracts on cell viability is present in Fig. 1. We observed that ethanolic extract $(\mathrm{EtOH})$ reduced the number of viable Ehrlich tumor cells at $1 \mathrm{mg} / \mathrm{ml}$ (Basal: $95.73 \pm 3.76 ; 1 \mathrm{mg} / \mathrm{ml}$ : $49.38 \pm 19.33 ; 0.5 \mathrm{mg} / \mathrm{ml}: 88.32 \pm 4.13 ; 0.25 \mathrm{mg} / \mathrm{ml}: 97.88 \pm 1.30$ ) and spleen cells (Basal: $75.51 \pm 6.83$; $1 \mathrm{mg} / \mathrm{ml}: 56.14 \pm 8.35 ; 0.5 \mathrm{mg} / \mathrm{ml}: 66.35 \pm 8.07 ; 0.25 \mathrm{mg} / \mathrm{ml}: 71.27 \pm 6.96)$. Hexane extract showed no toxic effect on Ehrlich cells (Basal: $91.37 \pm 2.31 ; 1 \mathrm{mg} / \mathrm{ml}: 89.75 \pm 11.11 ; 0.5 \mathrm{mg} / \mathrm{ml}: 96.00 \pm 1.57 ; 0.25 \mathrm{mg} / \mathrm{ml}: 88.93$ \pm 3.89 ), but $1 \mathrm{mg} / \mathrm{ml}$ and $0.5 \mathrm{mg} / \mathrm{ml}$ affected the viability of spleen cells (Basal: $89.07 \pm 4.47 ; 1 \mathrm{mg} / \mathrm{ml}: 64.16 \pm$ 5.59; $0.5 \mathrm{mg} / \mathrm{ml}: 70.66 \pm 5.83 ; 0.25 \mathrm{mg} / \mathrm{ml}: 82.84 \pm 6.10)$. Ethyl acetate extract reduced the viable tumor cells (Basal: $99.47 \pm 0.65 ; 1 \mathrm{mg} / \mathrm{ml}: 94.41 \pm 3.00 ; 0.5 \mathrm{mg} / \mathrm{ml}: 95.16 \pm 2.07 ; 0.25 \mathrm{mg} / \mathrm{ml}: 97.04 \pm 3.87$ ) and splenic (Basal: $77.06 \pm 1.96 ; 1 \mathrm{mg} / \mathrm{ml}: 56.36 \pm 14.60 ; 0.5 \mathrm{mg} / \mathrm{ml}: 74.67 \pm 6.99 ; 0.25 \mathrm{mg} / \mathrm{ml}: 76.67 \pm 5.09$ ).

\subsection{Effect of Ethanolic Extract on Solid Ehrlich Tumor}

In order to evaluate whether copaiba ethanolic extract has antitumor effect a solid tumor, mice bearing subcutaneously Ehrlich tumor were treat with this extract at $200 \mathrm{mg} / \mathrm{kg}, 150 \mathrm{mg} / \mathrm{kg}$ or $100 \mathrm{mg} / \mathrm{kg}$ during 30 days (Fig. 2). After 30 days, mice treated with $200 \mathrm{mg} / \mathrm{kg}$ showed the lower tumor growth than control group (EtOH 100mg/kg: $1.49 \pm 0.52 ; \mathrm{EtOH} 150 \mathrm{mg} / \mathrm{kg}: 1.29 \pm 0.55 ; \mathrm{EtOH} 200 \mathrm{mg} / \mathrm{kg}: 0.87 \pm 0.53$ and Control: $1.31 \pm 0.67)$. Growth inhibition of solid tumor was about $45 \%$ and being selected for lymphocyte proliferation assay and cytokines determination.

\subsection{Effect of Ethanolic Extract on Lymphoproliferative Activity}

Analysis of 14 days shows a reduced lymphoproliferative activity in mice (EHR/EtOH: $21.80 \pm 17.52$ and EtOH: $40.90 \pm 39.92$ vs EHR: $67.88 \pm 35.50$ and control: $53.62 \pm 40.93$, respectively) (Fig. 3). We observed that implantation of Ehrlich tumor cells increased the lymphoproliferation activity of spleen cells, while administration of extract strongly decrease such effect (EHR/EtOH). However, administration of extract in normal mice did not have this suppressive effect. 

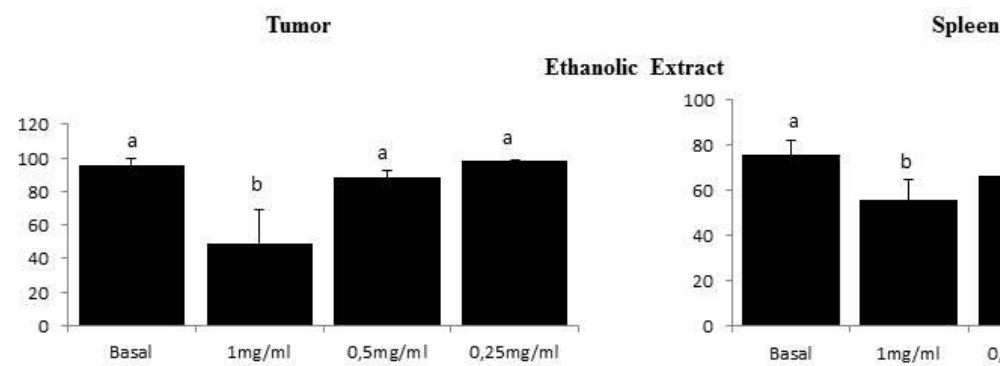

Spleen

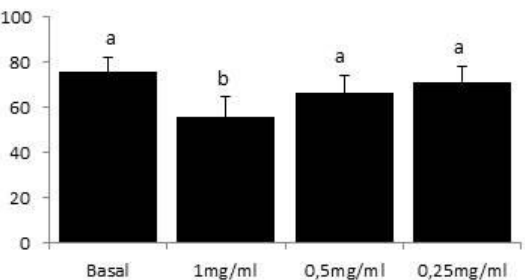

Hexane Extract
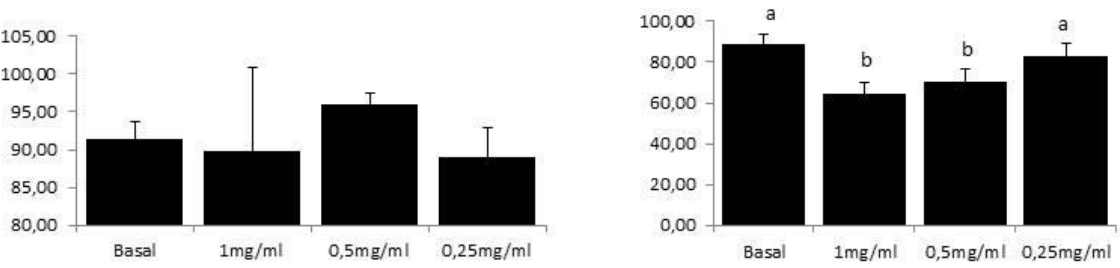

Ethyl acetato Extract
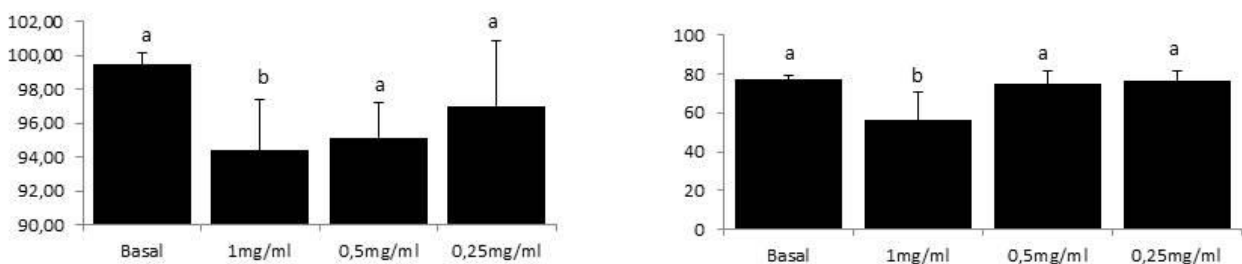

Basal

$1 \mathrm{mg} / \mathrm{ml}$

$0,5 \mathrm{mg} / \mathrm{m}$

$0,25 \mathrm{mg} / \mathrm{ml}$

Figure 1 - Ehrlich tumor cell and splenic cell viability treated with different copaiba extract for 24 hours at $37^{\circ} \mathrm{C}$ under $5 \% \mathrm{CO}_{2}$. Basal: RPMI $20 \% \mathrm{SBF}$ The viability was assessed by Trypan blue exclusion method in a Neubauer chamber. Mean values \pm standard deviation expressed in percentages. Lowercase letters: treated groups comparis on with control

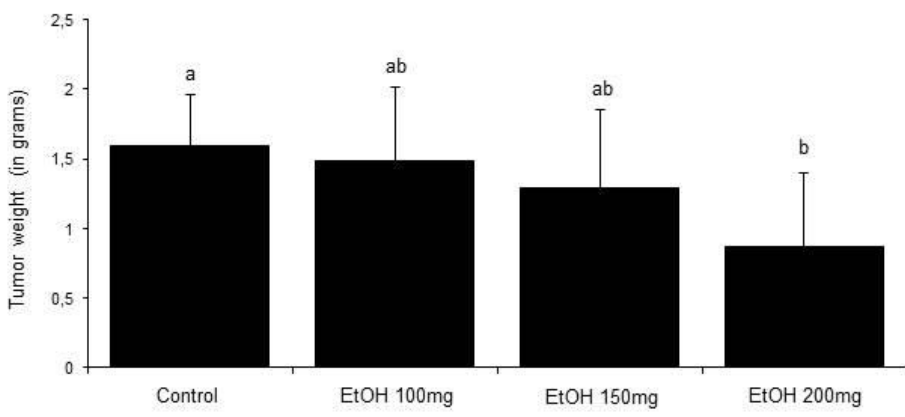

Figure 2 - Ehrlich tumor growth assessment in Swiss mice treated (gavage) with different concentration of ethanolic copaiba extract (EtOH) or buffered saline solution (Control) for 30 days. Percentage of growth inhibition of solid tumor was calculated by formula: [\% inhibition $=100 x\{$ (tumor weigh control mean tumor weigh treatment mean)/tumor weigh control mean\}]. The values are expressed as mean \pm standard deviation of tumor mass in grams. 


\subsection{Effect of ethanolic extract on cytokines production}

The cytokine ex vivo production was assessed in spleen cells culture supernatants stimulated with Con A (24h) or SAC (48h) (Fig. 4). We observed that treatment with EtOH (200 mg/ml) for 7 days induced higher levels of IFN- $\gamma(1,425.98 \pm 833.08)$ compared with EHR control group (306.34 \pm 576.36$)$. In addition, treatment induced a drastic increase of IL-12p70 (159.41 \pm 95.73) and TNF- $\alpha(1,042.2 \pm 103.08)$ when compared to control group (IL-12p70: $60.7 \pm 24.47$; TNF- $\alpha$ : $595.27 \pm 228.53)$ and the EtOH (TNF- $\alpha: 472.57 \pm 465.35) \mathrm{e}$ EHR group (TNF- $\alpha$ : $526.95 \pm 299.95)$. In contrast, there was no difference on IL-4 production among studied groups (Control: $65.14 \pm$ 28.65; EtOH: $67.69 \pm 34.99$; EHR: $53.90 \pm 13$, 49; EHR/EtOH: $48.68 \pm 18.79$ ). After 14 days of treatment, there was no difference on cytokine production among studied groups.

These results suggest that in early periods, the immune response against the tumor has a proinflammatory profile with increased production of IFN- $\gamma$ and TNF- $\alpha$.

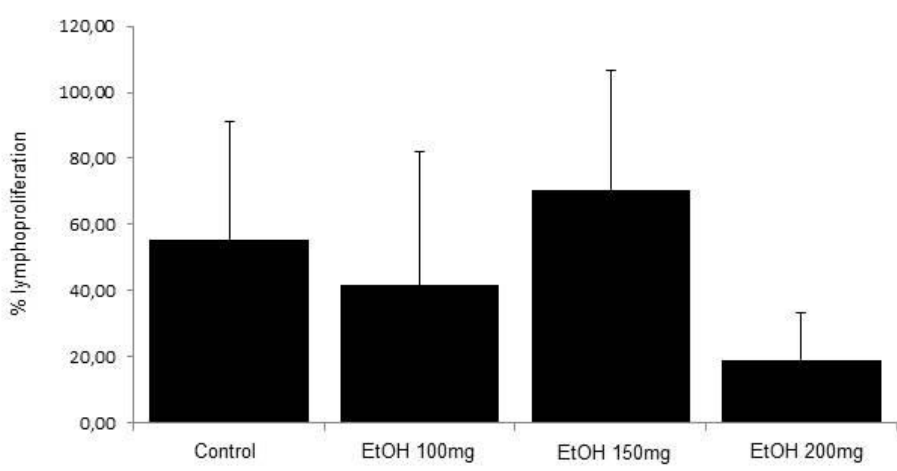

Figure 3 - Lymphoproliferative activity of spleen cells in Swiss mice treated with $200 \mathrm{mg} / \mathrm{Kg}$ of ethanolic copaiba extract for 14 days. The lymphoproliferative activity of spleen cells was calculated according to the following formula: \% lymphoproliferation $=[$ (DO Con A-DO basall)/(DO basal) $)] \times 100$. The values are expressed as mean \pm standard deviation. 


\section{7 days}

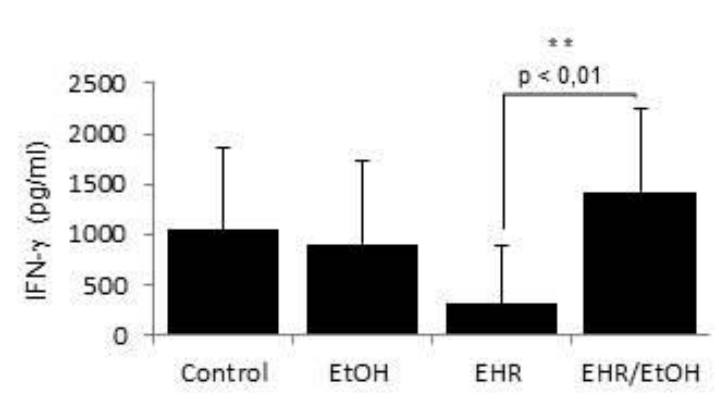

A

14 days
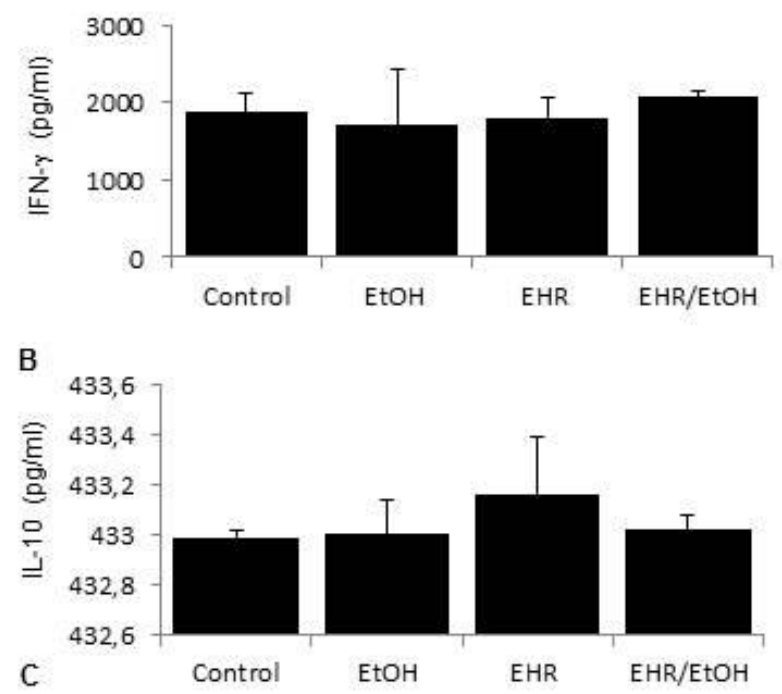
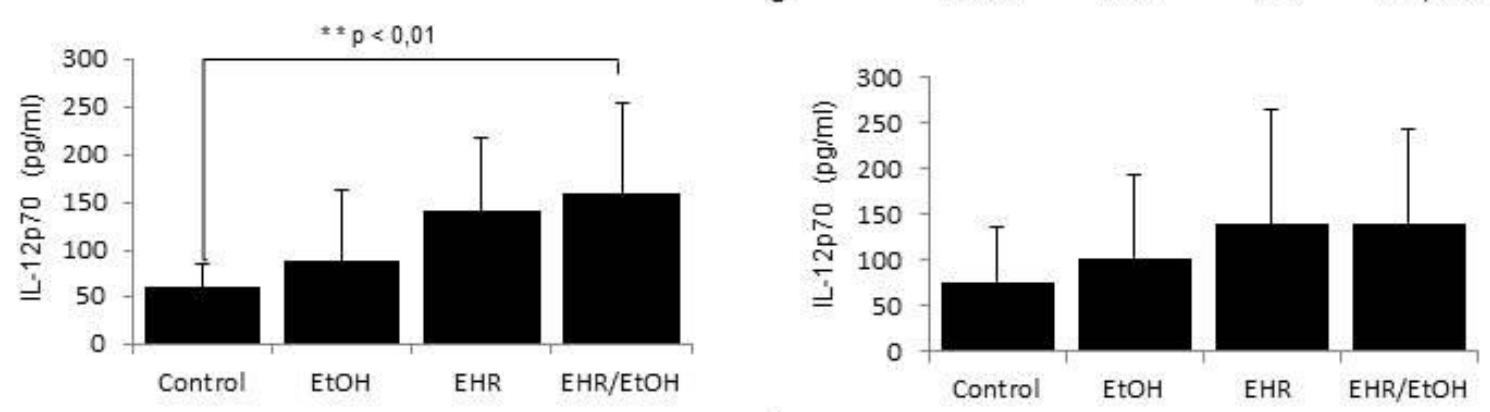

D
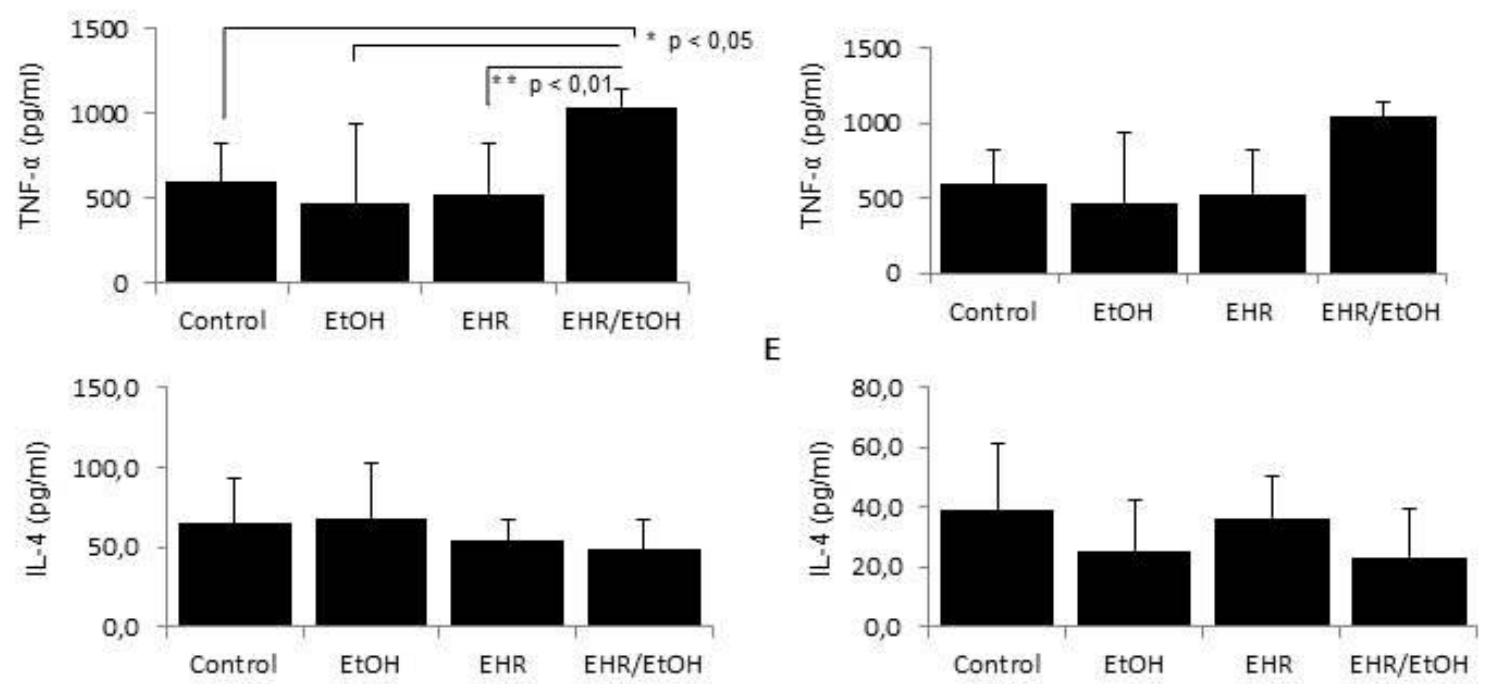

Figure 4-Cytokines production in culture supernatants of spleen cells in Swiss mice treated with $200 \mathrm{mg} / \mathrm{Kg}$ of ethanolic copaiba extract $(\mathrm{EtOH})$ for 7 or 14 days. Cell culture supernatant stimulated ex vivo with Con $\mathrm{A}(3.5 \mu \mathrm{g} / \mathrm{ml})$ for $24 \mathrm{~h}$ to IFN-7 (A), IL-10 (B) and II-4 (E) analysis or Staphylococos cureus formalized cells $(1: 5,000)$ for $48 \mathrm{~h}$ to generate IL-12p 70 (C) and TNF- $\alpha$ (D). The values are expressed as mean $=$ standard deviation. Quantification of cytokines production was done byELISA and the reaction was read by spectrophotometry under $450 \mathrm{~nm}$ (LabSystems - Finland). Data from the standard curve were submitted to linear regression analysis and the results of samples were expressed as $\mathrm{pg} / \mathrm{ml}$. 


\section{Discussion}

The results demonstrated that treatment of animals with ethanolic extract at a $200 \mathrm{mg} / \mathrm{Kg}$ induced tumor regression in $45.28 \%$. This effect may be associated with direct action of the extract on the tumor cells, as observed on the in vitro cytotoxicity studies, or it might derive from the modulation of the immune system from the cytokine production stimulation, as TNF- $\alpha$, IL-12 and IFN- $\gamma$ after 7 days of treatment.

Many different studies demonstrate the antitumor effect of extracts made from different species of copaiba. Gomes et al [7] observed significant inhibition of Ehrlich ascitic tumor associated to the inhibition of inflammatory mediators $\left(\mathrm{PGE}_{2}\right.$, nitric oxide and TNF- $\alpha$ ) and the reversion of hematopoietic suppression, in animals treated with 100,150 or $200 \mathrm{mg} / \mathrm{Kg}$ of C. multijuga oil-resin, and the results were similar to those observed in hexanic and chloroformic fractions. Lima et al [6] observed the oral administration of C. Multijuga Hayne oil-resin $(2 \mathrm{~g} / \mathrm{Kg})$ has reduced the growth of murine melanoma B16F10 in $58 \%$ and tumor weight in $76 \%$.

The biological effect of the copaiba oil is specially attributed to some compounds with antiinflammatory action, such as $\beta$-caryophyllene [5,10] and copalic acid [11]. In vitro studies suggest that $\beta$ caryophyllene is a dietary cannabinoid with important anti-inflammatory effects through the inhibition of cannabinoid type-2 receptor [10]. Sesquiterpene binds selectively to cannabinoid type-2 receptor inhibing proinflammatory pathways, including toll-like receptor complex CD14/TLR4/MD2, which normally leads to the expression of IL-1 $\beta$, IL-6, IL-8 and TNF- $\alpha$. The inhibition of pro-inflammatory cytokine production may also be a result of NF- $\mathrm{KB}$ nuclear translocation inhibition [13].

In a comparative study about chemical composition and anti-inflammatory activity of copaiba oil from the $C$. cearensis Huber ex Ducke, $C$. reticulata Ducke and C. multijuga Hayne, Veiga-Junior et al [5] observed that $C$. multijuga showed the most potent anti-inflammatory effect was able to inhibit NO production and leukocyte accumulation in the model of Zimosan-induced pleurisy. This effect can be explained by the higher concentration of $\beta$-caryophyllene (57.5\%) in the C. multijuga [5].

In this research, we use Ehrlich tumor model, a transplantable, poorly differentiated, malignant tumor that appeared initially as a spontaneous murine mammary adenocarcinoma [13]. In our study, the inhibition of tumor growth was accompanied by the stimulation to the TNF- $\alpha$, IL-12p70 and IFN- $\gamma$ production. Santiago et al [11] have also observed this pro-inflammatory effect, in which the incubation of different concentrations of copaiba oil maintained the LPS-induced TNF- $\alpha$ production by human monocytes. The same profile has been observed to IL-10 and the treatment with EtOH has resulted on the inhibition of IL-10 production in comparison to the tumor stimulation. Santiago et al [11] also corroborated this result.

Despite of this Th1 pattern from antitumor response to the 7-day treatment, the reduction of the tumor growth was followed by an apparent reduction on the lymphoproliferation (14 days), also observed in normal animals that were treated with the plant extract. Such effect can be a result of the direct cytotoxicity, evinced by the in vitro tests for the tumor, but for the spleen cells as well.

Copaiba cytotoxic effects have already been described on literature. Veiga-Junior et al [5] demonstrated that oil-resin from C. multijuga Hayne and C. cearensis Hber ex Ducke were cytotoxic at $500 \mathrm{ug} / \mathrm{ml}$, reducing the number of viable macrophages by 95 and $94 \%$, respectively, whereas at the concentration of $50 \mathrm{ug} / \mathrm{ml}$, more than $93 \%$ of the cells remain viable. Lima et al [6] showed that B16F10 cells viability was severely reduced as the time of incubation with the plant oil-resin increased. Costa-Lotufo et al. [14] observed cytotoxic and antiproliferative effect of kaurenoic acid, an isolated diterpene from C. langsdorffii oil-resin, on the leukaemic cells, with reduction at a 95\% on tumor growth, on the MCF-7 cell and HCT-8 cell with reduction at a $47.5 \%$ on tumor growth each. Besides, kaurenoic acid has inducted hemolysis to a $74.0 \mathrm{mM}$ for EC50 in rats erythrocytes and to $56.4 \mathrm{mM}$ in human erythrocytes [14]. Gelmini et al [12] demonstrated the antiproliferative effects on the psoriasis treatment with $C$. langsdorffii oil-resin.

In fact, our results also made clear the cytotoxic effect of the ethanol, ethyl acetate and hexanic extract, especially at higher concentrations $(1 \mathrm{mg} / \mathrm{ml})$ and independently dosed. According to Veiga-Junior et al [5], this effect may be a result of the presence of toxic substance, such as caryophyllene oxide.

It is important to highlight that, although the inflammatory response is essential to Ehrlich tumor controlling, the higher influx of neutrophils and monocytes cells promotes tumor development, probably related to the angiogenesis and growing factors production by cells [7]. This way, treatment with C. multijuga oil and its fraction, despite its well-related anti-inflammatory activity, may be one possible explanation for the reduction of Ehrlich tumor growth [7].

Another important aspect is that copaiba extracts may reflect a dependent dose effect, acting similarly to an anti-inflammatory in low doses, similar to NSAID, or to an immunosuppressive in high doses, similar to glucocorticoids [8].

Unlike most of the studies that rated the biological effect of copaiba oil-resin or its fraction, in this study, we used an ethanolic fraction of the bark of the plant. A preliminary phytochemical screening demonstrated the presence of secondary compounds, such as taninus, saponins, flavonoids and alkaloids, being $747.57 \mathrm{mgEAG} / \mathrm{g}$ of total phenols on the bark of the plant (data not shown). These data are corroborated by 
Monteiro et al [15], in which 33.3mg/g of taninus was observed in C. langsdorffii Desf oil-resin, and by CostaMachado et al [16], that showed a total of $1.35 \mathrm{mg} / \mathrm{ml}$ phenols in C. langsdorffii Desf oil-resin.

Studies with ethanolic extract from $C$. langsdorffii leaves demonstrated the presence of the following substances: quercetin [17,18], afzelin [17] and kaempferol [18], phenol compounds from flavonoids groups.

Flavonoids present antioxidant activity due to their capacity to absorb free radicals, functioning as a hydrogen donor [17] and as an inhibitor of lipid peroxidation [18].

In our group, we observed ethanolic extract of the copaiba bark administration during 30 days to Ehrlich tumor-bearing mice caused a reduction on the levels of 2-Thiobarbituric Acid Reactive Substances (TBARS) and an increase on the catalase activities and reduced glutathione (GSH), compared to the not treated group (data not shown). Therefore, a significant reduction in TBARS levels and significant elevation of GSH and catalase by the extract treatment confirms the potent antioxidant and free radical scavenger activity of copaiba ethanol extract and show their potential to reduce oxidative stress from tumor-bearing mice, reducing the cellular damage associated to cancer [19].

A decrease in endogenous antioxidant enzymes with enhanced free radical generation and lipid peroxidation is well documented in carcinogenesis [13]. Several reports documented that the product of lipid peroxidation (TBARS) is considered higher in cancer tissues than it is in normal tissues [13,19]. GSH plays an important role in endogenous antioxidant system and it is a potent inhibitor of the neoplasic process, found at low concentration in cancer tissues and at higher concentration in normal tissues [13]. The two enzymes present in free radical scavenging system are superoxide dismutase and catalase $[13,19]$. The main function of these two enzymes is to provide defense against the superoxide anions and hydrogen peroxide [13]. The inhibition of catalase activities because of tumor growth was also reported ([13,19].

\section{Conclusion}

We conclude that the reduction of Ehrlich tumor growth observed in animals, which were treated with copaiba bark ethanolic extract, was a result from the association of different biological effects inducted by the treatment. 1) Due to the stimulation of the immune system on initial phases of tumor growth, that inducts the cytokine production with antitumor effects. 2) Due to the anti-inflammatory effects inducted after 14 days, which might also have reduced angiogenic factors favorable to tumor growth. 3) Due to the direct cytotoxic action on tumor cells.

Another important observation is that the biological effect of raw extract of plants reflects the complexity of compounds with different mechanisms of action and concentrations, so the effect of these compounds together presents itself more efficient than the individual effects $[3,18]$. Besides, we must consider the influence of pharmacokinetics parameters of the oral administration $[3,6,7]$ and great seasonal fluctuations from the compounds present in the plants as a consequence of the period of the collection [4].

\section{References}

[1]. F.L. Westphal, L.C. Lima, R.A. Guimarães, R.F.S. Souza, S.B. Couto, S.R. Nakajima, Avaliação das alterações pleuropulmonares após a injeção de óleo de resina de copaíba, extrato aquoso de crajiru e polivinilpirrolidona iodado (PVPI) na pleura e parênquima pulmonar de ratos, Rev. Col. Bras. Cir, 34, 2007, 170-176.

[2]. F.A. Pieri, M.C. Mussi, M.A.S. Moreira, Óleo de copaíba (Copaifera sp.): histórico, extração, aplicações industriais e propriedades medicinais, Res. Bras. Pl. Med, 11, 2009, 465-472.

[3]. N.M. Gomes, C.M. Rezende, S.P. Fontes, M.E. Matheus, A.C. Pinto, P.D. Fernandes, Characterization of the antinociceptive and anti-inflammatory activities of fractions obtained from Copaifera multifuga Hayne, Journal of Ethnopharmacology, 128, 2010, 177183.

[4]. V.F. Veiga Junior, L. Zunino, M.L. Patitucci, A.C. Pinto, J.B. Calixto, The inhibition of paw oedema formation caused by the oil of Copaifera multifuga Hayne and its fractions, Journal of Pharmacy and Pharmacology, 58, 2006, 1405-1410.

[5]. V.F. Veiga Junior, E.C. Rosas, M.V. Carvalho, M.G.M.O. Henriques, A.C. Pinto, Chemical composition and anti-inflamatory activity of copaíba oils from Copaifera cearensis Huber ex Ducke, Copaifera reticulata Ducke and Copaifera multifuga Hayne - a comparative study, Journal of Ethnopharmacology, 112, 2007, 248-254.

[6]. S.R.M. Lima, V.F. Veiga Junior, H.B. Christo, A.C. Pinto, P.D. Fernandes, In vivo and in vitro studies on the anticancer activity of Copaifera multifuga Hayne and its fractions, Phytotherapy Research, 17, 2003, 1048-1053.

[7]. N.M. Gomes, C.M. Rezende, S.P. Fontes, A.M.C. Hovell, R.G. Landgraf, M.E. Matheus, A.C. Pinto, P.D. Fernandes, Antineoplasic activity of Copaifera multijuga oil and fractions against ascitic and solid Ehrlich tumor, Journal of Ethnopharmacology, 119, 2008, 179-184.

[8]. N.M.B. Brito, M.V.H. Brito, R.K.V. Carvalho, L.T.M. Moura, B. Matos, R.C. Lobato, S.C. Correa, R.B. Brito, The effect of copaiba balsam on Walker 256 carcinoma inoculated into the vagina and uterine cervix of female rats, Acta Cirúrgica Brasileira, $25,2010,176-180$.

[9]. N.M. Botelho, S.C. Corrêa, R.C. Lobato, R.K.R.C. Teixeira, J.A.S. Quaresma, Immunohistochemistry of the uterine cervix of rats bearing the Walker 256 tumor treated with copaiba balsam, Acta Cirúrgica Brasileira, 28, 2013, 185-189.

[10]. A. Guimarães -Santos, D.S. Santos, I.R. Santos, R.R. Lima, A. Pereira, L.S. Moura, R.N. Carvalho JR., O. Lameira, W. GomesLeal, Copaiba oil-resin treatment is neuroprotective and reduces neutrophil recruitment and micróglia activation after motor córtex excitotoxic injury, Evidence-Based Complementary and Alternative Medicine, 2012, 2012, 1-9.

[11]. K.B. Santiago, B.J. Conti, B.F.M.T. Andrade, J.J.M. Silva, H.L.G. Rogez, E.J. Crevelin, L.A.B. Moraes, N.I. R. Venezia, S.R. Ambrosio, J.K. Bastos, J.M. Sforcin, Immunomodulatory action of Copaifera spp oleoresins on cytokine production by human monocytes, Biomedicine \& Pharmacotherapy 70 (2015) 12-8. 
[12]. F. Gelmini, G. Beretta, C. Anselmi, M. Centini, P. Magni, M. Ruscica, A. Cavalchini, R.M. Facino, GC-MS profiling of the phytochemical constituents of the oleoresin from Copaifera langsdorffi Desf. and a preliminar in vivo evaluation of its antipsoriatic effect, Internacional Journal of Pharmaceutics, 440, 2013, 170-178.

[13]. P.K. Sumadrala, B.B. Augustine, E.R. Kasala, L.N. Bodduluru, C. Barua, M. Lahkar, Evaluation of antitumor activity and antioxidante status of Alternanthera brasiliana against Ehrlich ascites carcinoma in Swiss albino mice, Pharmacognosy Research, 7, 2015, 66-73.

[14]. L.V. Costa-Lotufo, G.M.A. Cunha, P.A.M. Farias, G.S.B. Viana, C. Pessoa, M.O. Moraes, E.R. Silveira, N.V. Gramosa, V.S.N. Rao, The cytotoxic and embryotoxic effects of kaurenoic acid, a diterpene isolated from Copaifera langsdorffii oleo-resin, Toxicon, 40, 2002, 1231-1234.

[15]. J.M. Monteiro, J.S.N. Souza, E.M.F.L. Neto, K.S.E.F. Trindade, Does total tannin content explain the use value of spontaneous medicinal plants from the Brazilian semi-arid region?, Revista Brasileira de Farmacognosia, 24, 2014, 116-123.

[16]. A.R.M. Costa-Machado, J.K. Bastos, L.A.P. Freitas, Dynamic maceration of Copaifera langsdorffii leaves: a technological study using fractional factorial design, Revista Brasileira de Farmacognosia, 23, 2013, 19-85.

[17]. J.M. Alves, C.C. Munari, M.A.B. Monteiro Neto, R.A. Furtado, J.M. Senedese, J.K. Bastos, D.C. Tavares, In vivo protective effect of Copaifera langsdorffii hydroalcoholic extract on micronuclei induction by doxorubicin, Journal of Applied Toxicology, 33, 2012, 854-860.

[18]. J.M. Senedese, J.M. Alves, I.M.S. Lima, E.A.P. Andrade, R.A. Furtado, J.K. Bastos, D.C. Tavares, Chemopreventive effect of Copaifera langsdorffii leaves hydroalcoholic extract on 1,2-dimethylhydrazine-induced DNA damage and preneoplastic lesions in rat colon, BMC Complementary \& Alternative Medicine, 13, 2013, 1-8.

[19]. N.B. Pandya, I.P. Tigar, K. Dupadahalli, H. Kamurthy, R.R. Nadendla, Antitumor and antioxidante status of Terminalia catappa against Ehrlich ascites carcinoma in Swiss albino mice, Indian Journal of Pharmacology, 45, 2013, 464-469. 